\section{Morphoanatomic and histochemical aspects of Elaeis oleifera (Kunth) Cortés seed}

\author{
Suelen Cristina de Sousa Lima ${ }^{1^{*}}\left(\mathbb{D}\right.$, Poliana Roversi Genovese-Marcomini ${ }^{\mathbb{D}}$, \\ Regina Caetano Quisen ${ }^{3}\left(\mathbb{D}\right.$, Maria Silvia de Mendonça ${ }^{4}$ (D)
}

\begin{abstract}
Elaeis oleifera is an oleaginous palm tree native to America. The fruit contains unsaturated fatty acid extracted from the mesocarp. The species is mainly used in breeding programs of $E$. guineensis in development of interspecific hybrids with higher oil yield and resistance to lethal yellowing. E. oleifera is propagated by seed, which requires the adoption of methods for breaking dormancy and increasing the germination rate. However, there are no studies on the morphology and anatomy of the seed and its ergastic substances; knowing its structure makes it possible to improve planting methods and make them more effective. The aim of the present study was to describe the morpho-anatomy and histochemistry of the seed, characterizing it and contributing information that assists in understanding dormancy. In seeds collected in the experimental area of Embrapa Amazônia Ocidental (Amazonas), morpho-anatomical and histochemical analysis was conducted to detect metabolites (starch, protein, lipids, carbohydrates, and phenolic compounds). The seeds vary in shape, oblong and ovate. The embryo has an oblique embryonic axis, composed of root apical meristem and shoot apical meristem with three leaf primordia. Phenolic compounds were found throughout the seed coat; there are lipids, protein, and pectin in the embryo and endosperm.
\end{abstract}

Index terms: morphology, anatomy, palm tree.

\section{Aspectos morfoanatômicos e histoquímicos da semente de Caiaué (Elaeis oleifera (Kunth) Cortés)}

RESUMO: Elaeis oleifera é uma palmeira oleaginosa nativa da América. O fruto contém ácido graxo insaturado, extraído do mesocarpo. A espécie é explorada principalmente em programas de melhoramento genético de $E$. guineensis, no desenvolvimento de híbridos interespecíficos com maior produtividade de óleo e resistência ao amarelecimento fatal. A propagação de E. oleifera é realizada via semente que requer a adoção de metodologias para superação da dormência, e aumento da taxa de germinação. No entanto, não há estudos sobre a morfologia e anatomia da semente e suas substâncias ergásticas, conhecer a estrutura permite aprimorar e tornar efetivas as metodologias de plantio. $O$ presente trabalho teve como objetivo descrever a morfologia, anatomia e histoquímica da semente caracterizando-a e contribuindo com informações que auxiliem na compreensão da dormência. Em sementes coletadas na área experimental da Embrapa Amazônia Ocidental (Amazonas), foram realizados estudos morfoanatômicos e histoquímicos para detecção de metabólitos (amido, proteína, lipídeo, carboidrato e compostos fenólicos). As sementes apresentaram variação na forma, oblongas e ovadas. O embrião apresenta eixo embrionário obliquo composto por polo radicular e caulinar com três primórdios foliares. No tegumento verificou-se a presença de compostos fenólicos em toda extensão, no embrião e endosperma há presença de lipídeo, proteína e pectina.

Termos para indexação: morfologia, anatomia, palmeira.

Journal of Seed Science, v.42, e202042018, 2020

http://dx.doi.org/10.1590/2317$1545 v 42230138$

$*$ Corresponding author
E-mail: suelen.biologa23@gmail.

com

Received: $10 / 18 / 2019$ Accepted: 01/08/2020.

${ }^{1}$ Universidade Federal do Amazonas, Av. Rodrigo Otávio, 6200 - Setor Sul, Coroado, 69080-900 - Manaus, Amazonas, Brasil.

${ }^{2}$ Instituto Nacional de Pesquisa do Amazonas, Av. André Araújo, 2.936 Petrópolis, Caixa Postal: 2223, 69067-

375 - Manaus, Amazonas, Brasil.

${ }^{3}$ Embrapa Florestas, Estrada da Ribeira, Km 111 - Guaraituba, Caixa Postal: 319, 83411-000 - Colombo, Paraná, Brasil.

${ }^{4}$ LABAF/FCA/UFAM - Universidade Federal do Amazonas, Av. Rodrigo Otávio, 6200 - Setor Sul, Coroado, 69080-900 - Manaus, Amazonas, Brasil. 


\section{INTRODUCTION}

Palm trees are among the most diversified groups of plants; there are more than 150 species, with extraordinary variations in geographic distributions, regional patterns of abundance, and growth forms, and palm trees provide countless ecosystem services (Balslev et al., 2019). They are important for maintaining native fauna and flora; they interact with other plant species and serve as food and shelter for animals (Oliveira et al., 2010). For traditional populations, they are highly useful, as a food source - fruit and heart of palm; in craft production - the seed and vegetable matter; and in construction of dwellings - the stipe and the leaves. In addition, palm oils are widely used in the food, cosmetics, and medication industries (Oliveira and Rios, 2014).

Elaeis oleifera (Kunth) Cortés, popularly known as Caiaué in Brazil, belongs to the same genus as oil palm (Elaeis guineensis). It is native to the Americas, occurring in Mexico, Brazil, Colombia, Costa Rica, Ecuador, French Guiana, Honduras, Nicaragua, Panama, Peru, Suriname, and Venezuela (Meunier, 1975; Corley and Tinker, 2003; Cunha et al., 2012; Leitman et al., 2015). In Brazil, it more frequently occurs in the central region of the state of Amazonas, in wet and higher locations on firm soil (Oliveira and Rios, 2014).

In addition to natural populations, areas are planted to this species for experimental purposes and to maintain germplasm, especially because it represents a genetic resource of great interest for oil palm breeding programs (Arias et al., 2015). Traits of interest in the species include resistance to pests and diseases (especially lethal yellowing), a lower rate of vertical growth of the stipe, and oil of notable quality (Rios et al., 2012). Various breeding programs have already made interspecific hybrids between American oil palm and African oil palm (HIE OxG) available on the market, with commercial planted areas found mainly in Colombia, Brazil, and Ecuador, among other countries.

The oil palm breeding program conducted by Embrapa Amazônia Ocidental released the first HIE OxG, called BRS Manicoré (Cunha and Lopes, 2010), in 2009, which is grown mainly in the state of Pará, the area of occurrence of lethal yellowing (LY), an anomaly of yet unknown etiology that makes growing of oil palm unviable in that region.

Populations or progenies of E. oleifera are sexually reproduced, i.e., by seeds, which is an indispensable tool for ex situ maintenance and conservation of the germplasm of the species, in conducting breeding programs, and in establishing fields of parents for commercial production of hybrid seeds.

In general, under natural conditions, germination of Elaeis genus seeds is low and uneven, and may take years (Hussey, 1958). Various methods have been used with the aim of breaking seed dormancy in this crop. Among them, protocols with the use of thermal treatment by Hussey (1958) and Rees (1962) predominate, who observed the need to subject the seeds to a thermal treatment by heating. Green et al. (2013) and Lima et al. (2014) found that different genotypes respond in a particular manner in relation to moisture content and to the period of exposure of seeds in the thermal treatment. Lima et al. (2017) obtained germination rates from $72 \%$ to $76 \%$ through adjusting the seed moisture content of Caiaue from $20 \%$ to $23 \%$. Myint et al. (2010) scarified the seed, with removal of the operculum, and observed $88 \%$ germinated seeds in the period from three to eight days.

The studies conducted are only aimed at breaking dormancy, seeking to accelerate germination. Nevertheless, factors related to the morphology of the seed coat, such as number of cells, thickness of the cell wall, and presence of flavonoids (Debeaujon et al., 2007), as well as differentiation and maturation of the embryo, can affect germination (Hilhorst, 2007). According to Bewley (1997), complex interactions between the embryo and seed coat determine seed germination.

It is necessary to study the morphology, anatomy, and histochemistry of the seed coat to verify the level of dormancy and germination of the seed and to identify the factors that determine it (Debeaujon et al., 2007). The elements in the chemical composition of the seed can also affect germination, due to the presence of products of primary metabolism, such as carbohydrates, proteins, and lipids, which are consumed during germination by the embryo for formation of new cell structures (Carvalho and Nakagawa, 2012).

Due to the absence of studies on the structure of the Elaeis oleifera seed and the biological and economic contribution that knowledge of its morphology and anatomy will provide, the aim of the present study was to describe 
aspects of the morphoanatomy and histochemistry of the Elaeis oleifera seed, assisting understanding of its structure, and seeking to identify barriers that may affect germination.

\section{MATERIALS AND METHODS}

Fruit from E. oleifera was collected from plants of the Caiaué Active Germplasm Bank (Banco Ativo de Germoplasma de Caiaué - BAG) established at the Rio Urubu Experimental Station of Embrapa Amazônia Ocidental, Rio Preto da Eva, Amazonas (state), at 2035' S and 59-28' W.

Initially, controlled pollinations were carried out as described by Cunha et al. (2007) using Elaeis oleifera plants of Manicoré origin as male and female parents. In 2016 and 2017, five months after pollination, bunches were collected upon reaching physiological maturity, determined indirectly by natural detachment of three to five ripe coconuts, as has been adopted in commercial seed production.

Fruit was processed to obtain seeds according to the procedures presented by Lima et al. (2014). After obtaining the diaspores, formed by the endocarp and the true seed (endosperm + embryo) (Lima et al., 2014), they were placed in polyethylene bags and taken to the Agroforestry Botanical Laboratory of the School of Agrarian Sciences of the Universidade Federal do Amazonas.

Morphology, anatomy, histochemistry, and proximate analysis of the seed

To study morphology, the diaspores were squeezed in a vice to break the endocarp, remove the seed and make the longitudinal and transversal cuts. The color, consistency, and shape of the seed coat, endosperm, and embryo were observed in these segments with the aid of a magnifying glass and microscope. For biometric analysis, seeds from three identified plants were mixed (one hundred seeds each) from which length and width (basal and apical) were measured with a digital caliper rule, and the weight of each seed was determined with a precision $(0.0001 \mathrm{~g})$ balance (Brasil, 2009).

For anatomical study of the seed, fresh material in the seed coat and endosperm was cut transversally on a benchtop microtome, according to normal techniques in plant anatomy (Kraus and Arduin, 1997).

The embryos were removed from the seeds and fixed in FAA 70\% (formalin, acetic acid, and ethyl alcohol) (Kraus and Arduin, 1997), dehydrated in gradations of ethyl alcohol (70-95\%), soaked in 2-hydroxyethyl-methacrylate (Historesin ${ }^{\circledR}$ Leica), and suspended in blocks, according to manufacturer's instructions. The blocked material was cut in a manual rotary microtome with thickness from 5 to $7 \mu \mathrm{m}$ and stained with $0.5 \%$ toluidine blue in a citrate buffer, pH 4.0 (O'Brien et al., 1964), and slides were set up in water (Genovese-Marcomini et al., 2013). The parameters used in the morpho-anatomical descriptions and the terms placed on the structures are in accordance with the studies of Dransfield et al. (2008), Werker (1997), Tomlinson (1990), and Martin (1946).

The histochemical tests of the seed coat, endosperm, and embryo were applied on sections of fresh material obtained from a benchtop microtome from fragments of the seed coat and of the endosperm, and from the entire embryo, since it is small and does not require reduction in the size of the sample. This material was then stained with specific reagents for each substance, namely, Lugol's solution for detection of starch (Jensen, 1962), Xilidine Ponceau for detection of total proteins (O'Brien and McCully, 1981), Sudan Red III for detection of total lipids (Brundrett et al., 1991), ruthenium red for detection of pectins and mucilages (Johansen, 1940), Iron(III) chloride for detection of general phenolic compounds (Gabe, 1968), Wagner reagent for detection of alkaloids (Furr and Mahlberg, 1981), and phloroglucinol for detection of lignin (Johansen, 1940). The material was then examined under a microscope and images were registered.

Observation and photomicrographs in regard to the anatomical and histochemical study were obtained through the optical microscope Zeiss Primo Star coupled to the Canon Power Shot A650 IS digital photographic camera. Proximate composition analyses for determination of percentage of moisture, ash, lipids, proteins, and carbohydrates were carried out according to the method described by Horwitz and Latimer (2000) and Lutz (1985). 


\section{RESULTS AND DISCUSSION}

The seeds had a mean length of $14.15 \mathrm{~mm}$, apical diameter of $10.12 \mathrm{~mm}$, basal diameter of $10.75 \mathrm{~mm}$, and $0.93 \mathrm{~g}$ of fresh matter (Table 1). These measurements are near those of another palm tree of the same genus, Elaeis guineensis, which had mean diameter of $0.93 \mathrm{~mm}$ and weight of $0.99 \mathrm{~g}$ - mean values observed by Camillo et al. (2014) upon analyzing the biometry of seeds from eighteen bunches from different plants.

Seed moisture was $25.92 \%$ (Table 2). In studies conducted on Elaeis oleifera seeds and seeds from an oil palm with Caiaué hybrid, moisture content was found to affect germination. In seeds with a moisture content from $20 \%$ to $23 \%$ for Elaeis oleifera and from $19 \%$ to $22 \%$ for hybrid seeds, germination was greater than 70\% (Lima et al., 2014; 2017). Moisture content is of utmost importance since it is associated with the physiological quality of the seeds, which may favor their germination, and it can indicate the best period for collection and storage of the seeds from different species.

The longitudinal and transversal measurements in Elaeis oleifera seeds indicated variation in shape - seeds dorsoventrally flattened were observed, ovate or oblong (Figure $1 \mathrm{~A}$ ).

The seed coat is brown, with vascular extensions on its surface of a lighter shade and punctiform micropylar pore (Figure 1A). In Oenocarpus minor seeds there is variation in its shape and the same color of the seed coat (Mendonça et al., 2008).

The endosperm is white, with an oily, solid, and abundant appearance and is in direct contact with the seed coat (Figure 1B), a characteristic also observed in Butia capitata (Oliveira et al., 2013) and in Acrocomia aculeata (Souza et al., 2017).

The embryo is straight and occupies an apical position in the seed. It has two distinct regions, separated by a slight constriction: the proximal region, the shorter part of whitish yellow color, and the distal region, the more elongated part of pale white color (Figure 1C). According to Tomlinson (1990), embryos of palm seeds have a proximal region that accommodates the embryonic axis and a distal region that corresponds to the cotyledon blade. In some palm species, the proximal and distal regions of the embryo can be differentiated by a difference in coloring, as in Acrocomia aculeata (Moura et al., 2010), Mauritia flexuosa (Silva et al., 2014), and Butia capitata (Oliveira et al., 2013). In the Bactris gasipaes palm, the embryo has a homogeneous color, with the distal and proximal regions morphologically distinct (Nazário et al., 2013).

Anatomically, the Elaeis oleifera seed has a seed coat consisting of various juxtaposed layers of cells, from 12 to 15 (Figures 2A and 2B), which lend rigidity and impede the passage of light, acting as a regulator of germination. The arrangement of the seed coat cells reduces the intercellular spaces, contributing to impermeability to water, hindering gas diffusion, and affecting germination (Esau, 1977).

Table 1. Biometric characteristics of the Elaeis oleifera (Kunth) Cortés seed: mean values, amplitude, standard deviation $(\sigma)$, and coefficient of variation (CV) of the apical and basal width, length, and fresh matter.

\begin{tabular}{ccccc}
\hline Variable & Mean & Amplitude & Standard Deviation & CV (\%) \\
\hline Apical width $(\mathrm{mm})$ & 10.12 & $5.4 \pm 15.2$ & 1.97 & 19.5 \\
Basal width $(\mathrm{mm})$ & 10.75 & $5.4 \pm 17.5$ & 2.96 & 27.6 \\
Length $(\mathrm{mm})$ & 14.15 & $8.6 \pm 18.9$ & 2.13 & 15.1 \\
Weight $(\mathrm{g})$ & 0.93 & $0.4 \pm 1.9$ & 0.39 & 41.9 \\
\hline
\end{tabular}

Table 2. Proximate analysis percentages of Elaeis oleifera (Kunth) Cortés seeds.

\begin{tabular}{cccccc}
\hline Estimate (\%) & Moisture & Ash & Lipids & Proteins & Carbohydrates \\
\hline Mean & 25.92 & 1.82 & 24.4 & 8.35 & 39.51 \\
Standard Deviation & 0.29 & 0.04 & 0.01 & 0.3 & 1.31 \\
\hline
\end{tabular}




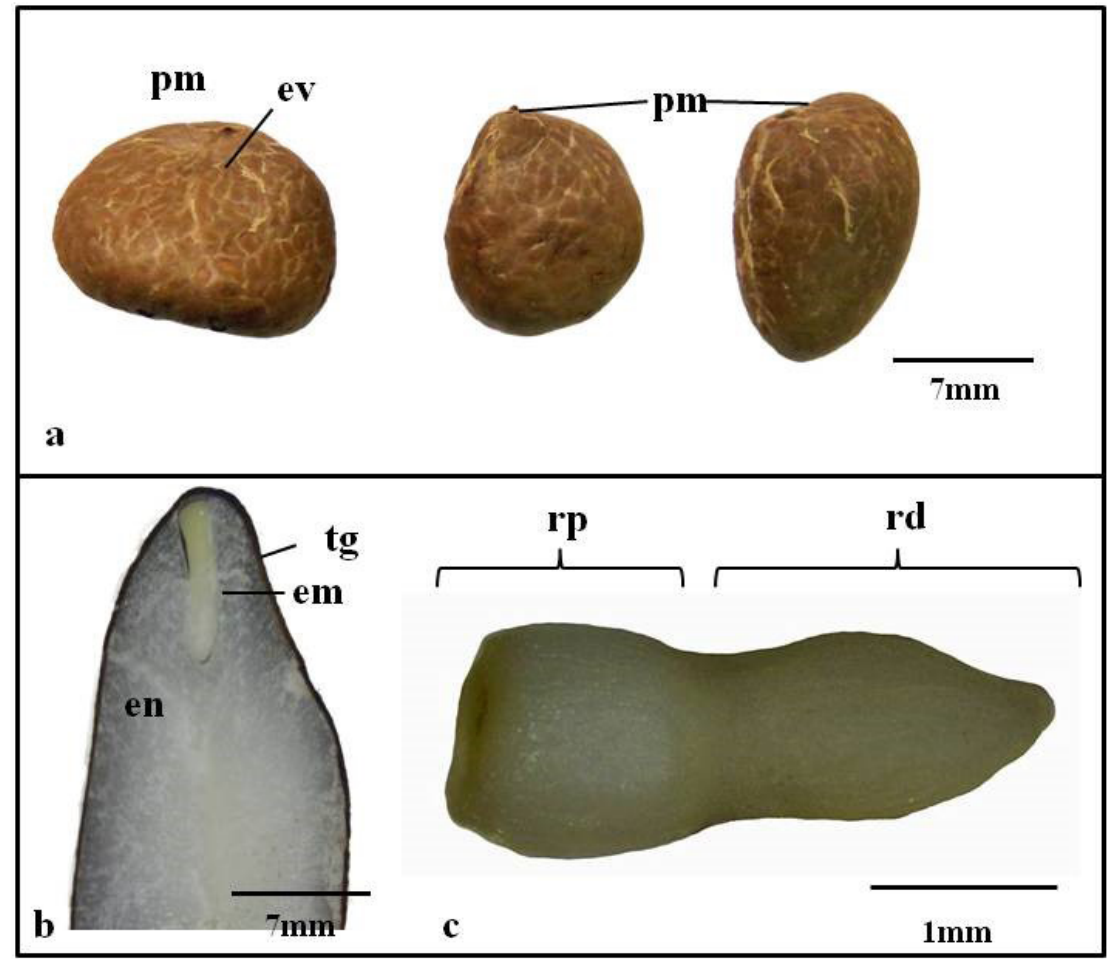

Figure 1. Seed morphology of Elaeis oleifera (Kunth) Cortés. a) Different shapes of the seed with micropylar pore and vascular extensions. b) Seed section in longitudinal cut showing seed coat, endosperm, and embryo. c) Embryo with proximal and distal region (pm: micropylar pore; ev: vascular extensions; en: endocarp; tg: tegument; ed: endosperm; em: embryo; rp: proximal region; rd: distal region).

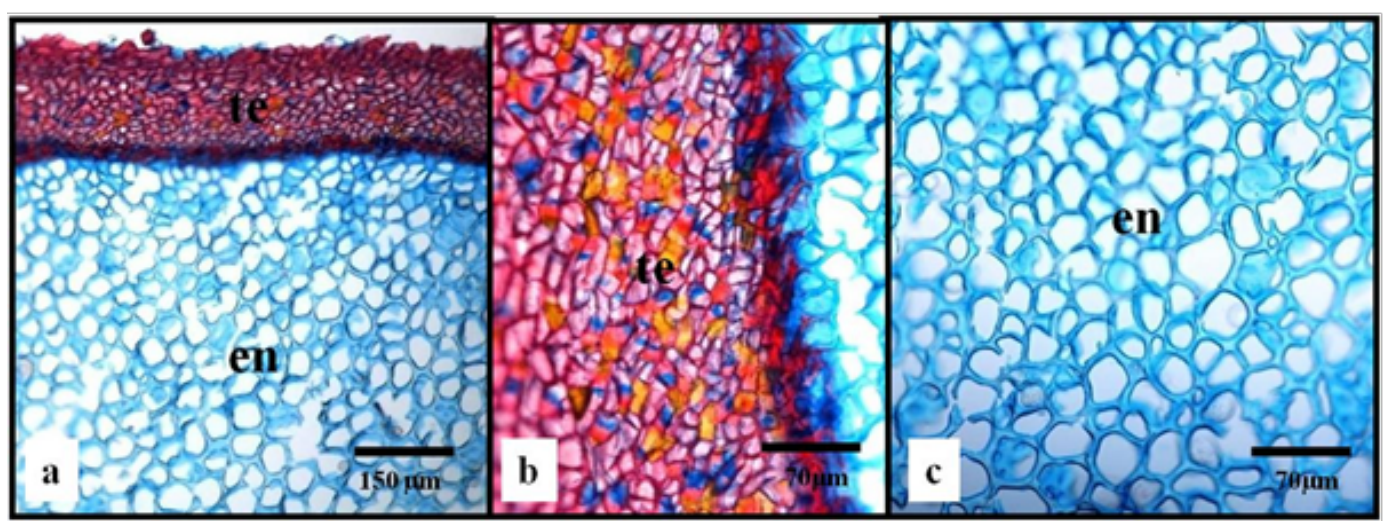

Figure 2. Seed of Elaeis oleifera (Kunth) Cortés in transversal cut. a) Seed coat and endosperm. b) Seed coat cells. c) Endosperm cells (te: tegument; en: endosperm).

The endosperm is formed of rounded cells, with dense walls, without intercellular spaces, and it occupies nearly all the inside of the seed (Figure 2C), characteristics also observed in Euterpe edulis, Washingtonia filifera and Phoenix dactylifera (Panza et al., 2004; DeMason, 1986; DeMason and Thomson, 1981). In Acrocomia aculeata, the cell walls are not overly dense, but pectins are noted in the cell walls, as well as in the middle lamella, which are also identified in small amounts in the inner wall (Moura et al., 2010).

The embryo is lined by the protoderm formed by juxtaposed cells, straight walls, and evident nucleus (Figures $3 \mathrm{~A}$ and $4 A-B)$. The embryonic axis of oblique position is in the proximal region, composed by two meristematic regions, the 
shoot meristem (plumule) and the root meristem. In the region of the root meristem, cells of smaller diameter, intensely ruddy, and in the shape of a shell are observed, the radicle; in the shoot meristem, which corresponds to the plumule, there are three leaf primordia that will form the first and second cataphyll and the eophyll, sequentially (Figures 3B-D and 4A), lined by a protoderm, as also observed in Acrocomia aculeata, Euterpe precatoria, and Syagrus inajai (Souza et al., 2017; Aguiar and Mendonça, 2003; Genovese-Marcomini et al., 2013). The distal region, which corresponds to the cotyledon blade, has a haustorial function, with an irregular surface and provascular bundles (Figures 3E and 4C-D). The cotyledonary gap appears in the direction of the apex of the leaf primordia, through which plumule emergence will occur at the time of germination (Figure 3B). The fundamental meristem is composed by cells with greater diameter than those of the proximal region, with various provascular bundles (Figure 4D) directed toward the periphery, near the protoderm, as observed in Syagrus inajai (Genovese-Marcomini et al., 2013). The embryo is found with its regions defined, as observed in Acrocomia aculeata, Bactris gasipaes, and Syagrus inajai (Ribeiro et al., 2012; Nazário et al., 2013; Genovese-Marcomini et al., 2013), thus discarding the idea of seed immaturity.

In relation to seed chemical composition, the greatest content was found for carbohydrates, with $39.51 \%$, followed by lipids, with $24.40 \%$ (Table 2). Carbohydrates and lipids are the nutritional compounds most found in palm. According to Barton and Crocker (1953), in Elaeis guineenses seeds, such compounds were found in different proportions: carbohydrates $28 \%$, lipids $49 \%$, and proteins $0.9 \%$. The presence of lipids does not refer only to species of Elaeis, but also to two subspecies of Acrocomia: A. aculeata sclereocarpa and A. aculeata sub. totai, exhibiting $55.42 \%$ and $47.76 \%$, respectively (Machado et al., 2015). Carbohydrates, lipids, and proteins are the main reserve substances in seeds, and the proportion varies according to the species (Marcos-Filho, 2015). They are synthesized in the seeds as reserve materials, to be used by the embryo during germination to constitute new cell structures (Henderson, 2002).

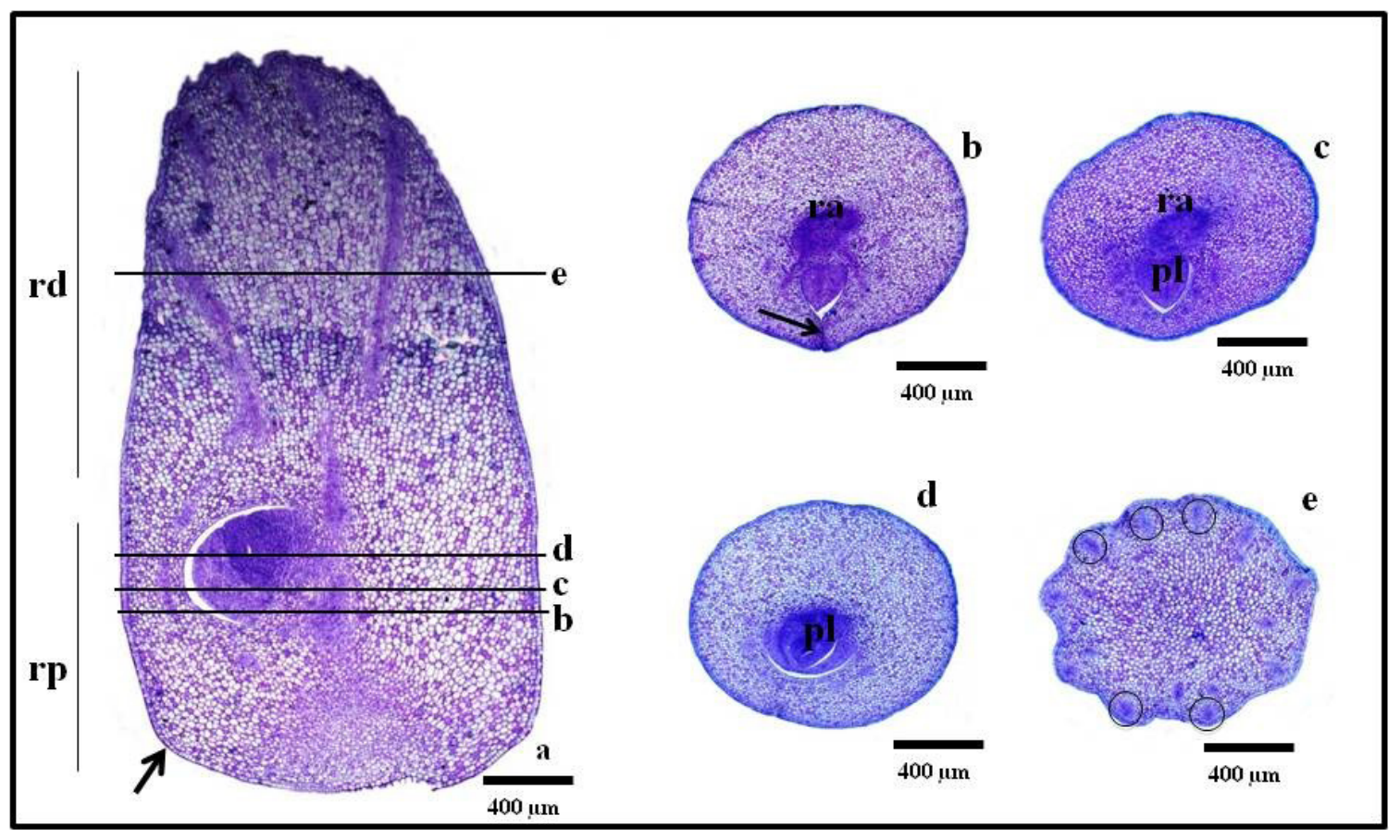

Figure 3. Embryo of Elaeis oleifera (Kunth) Cortés. a) Longitudinal section, showing the proximal region (embryonic axis) and the distal region (cotyledon blade or haustorium) protoderm (arrow). b) Cotyledon gap shown directed toward the apex of the leaf primordia (arrow).c) Embryonic axis, showing the radicle and plumule. d) Embryonic axis, showing the plumule. e) Distribution of the procambium in the distal region of the cotyledon blade (circle) (rp: proximal region; rd: distal region; ra: radicle; pl: plumule). 

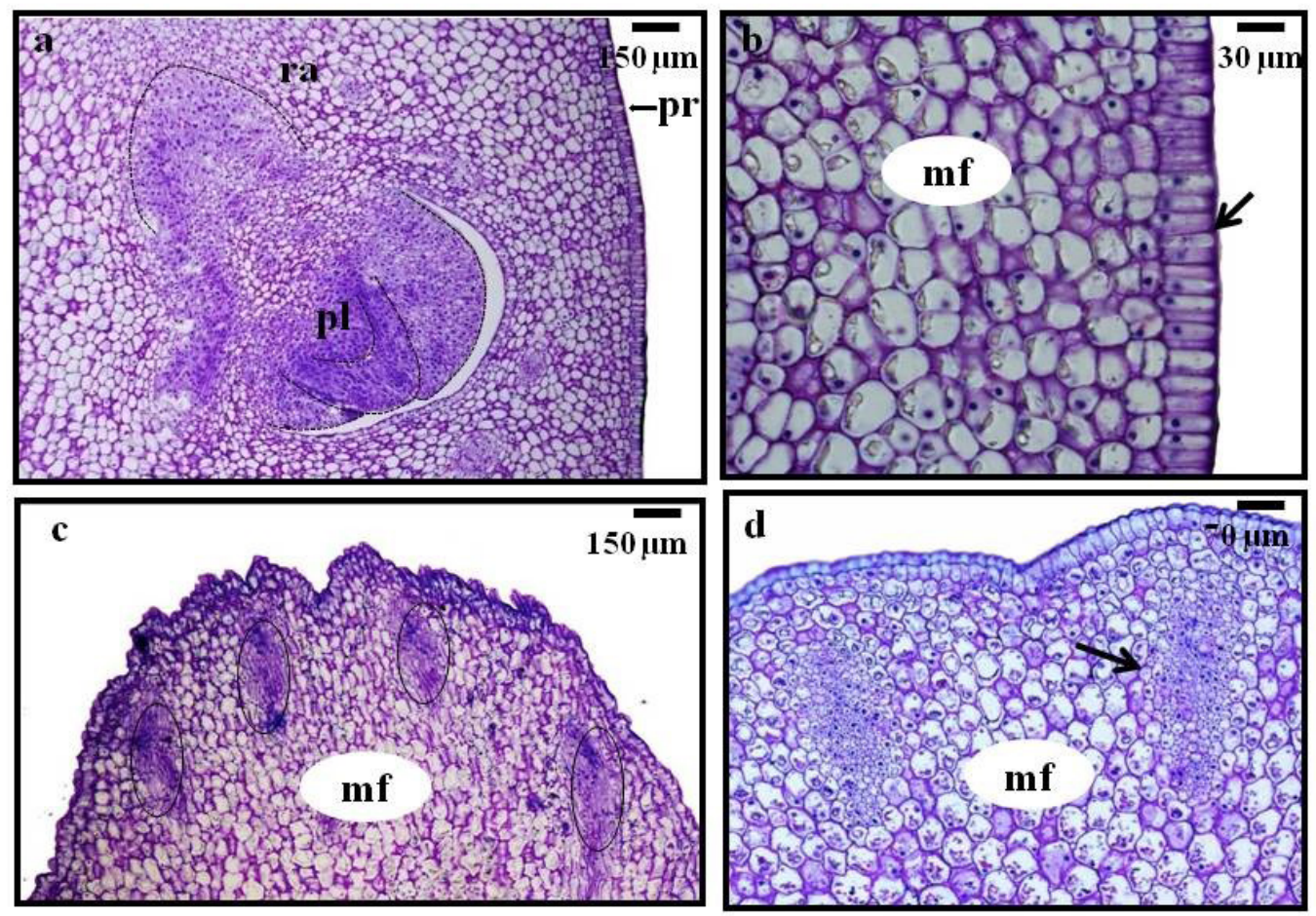

Figure 4. Embryo of Elaeis oleifera (Kunth) Cortés. a) Embryonic axis showing the radicle and the plumule. b) Cells of the fundamental meristem and protoderm (arrow) in the proximal region. c) Distal region showing the provascular bundles in dotted line. d) Procambium (arrow) near the protoderm in the distal region ( $p l$ : plumule; mf: fundamental meristem; pr: protoderm; ra: radicle).

In histochemical analyses performed in the seed, alkaloids appeared in the seed coat (Figure 5C). These metabolites play an important role in defense against herbivore insects and pathogens, in addition to allelopathic activity (Taiz and Zeiger, 2009).

Phenolic compounds were found in the seed coat of Elaeis oleifera. These inhibitors can restrict the entry of oxygen in the seed, impeding germination (Tokuhisa et al., 2007). Studies performed in Bactris maraja and Bactis gasipaes seeds indicated that organization of the seed coat cells, together with their phenolic composition, act as germination regulators, impeding germination (Rodrigues et al., 2015; Nazário et al., 2013). In Acrocomia aculeata (Moura et al., 2010), the presence of this compound and arrangement of the cells are likewise factors that hinder germination.

Pectins were identified in the cell walls of the endosperm cells (Figure 5A). They are generally found in the cell content in other species of the same family, such as Bactris maraja (Rodrigues et al., 2015), Bactris gasipaes (Nazário et al., 2013), and Attalea microcarpa (Melo et al., 2017). Pectins are polysaccharides, components of the cell wall that contain sugar and acids that contribute to adhesion among cells and mechanical resistance of the cell wall (Taiz and Zeiger, 2009).

Protein bodies were observed in large number of endosperm cells (Figure 5B), a component required to provide initial support of the seedlings until they become autotrophic organisms. Proteins are molecules constituted by nitrogen; they act as an energy source during seed germination (Buckeridge et al., 2004) and are commonly found in the endosperm of seeds of Attalea microcarpa (Melo et al., 2017), Bactris maraja (Rodrigues et al., 2015), Bactris gasipaes (Nazário et al., 2013), Euterpe oleraceae (Gonçalves et al., 2010), Acrocomia aculeata (Moura et al., 2010), and Euterpe edulis (Panza et al., 2004).

Lipids in the form of corpuscles were detected in the endosperm cells (Figure 5D). This compound is metabolized in the initial stages of germination and seedling establishment (Bewley and Black, 2012). 


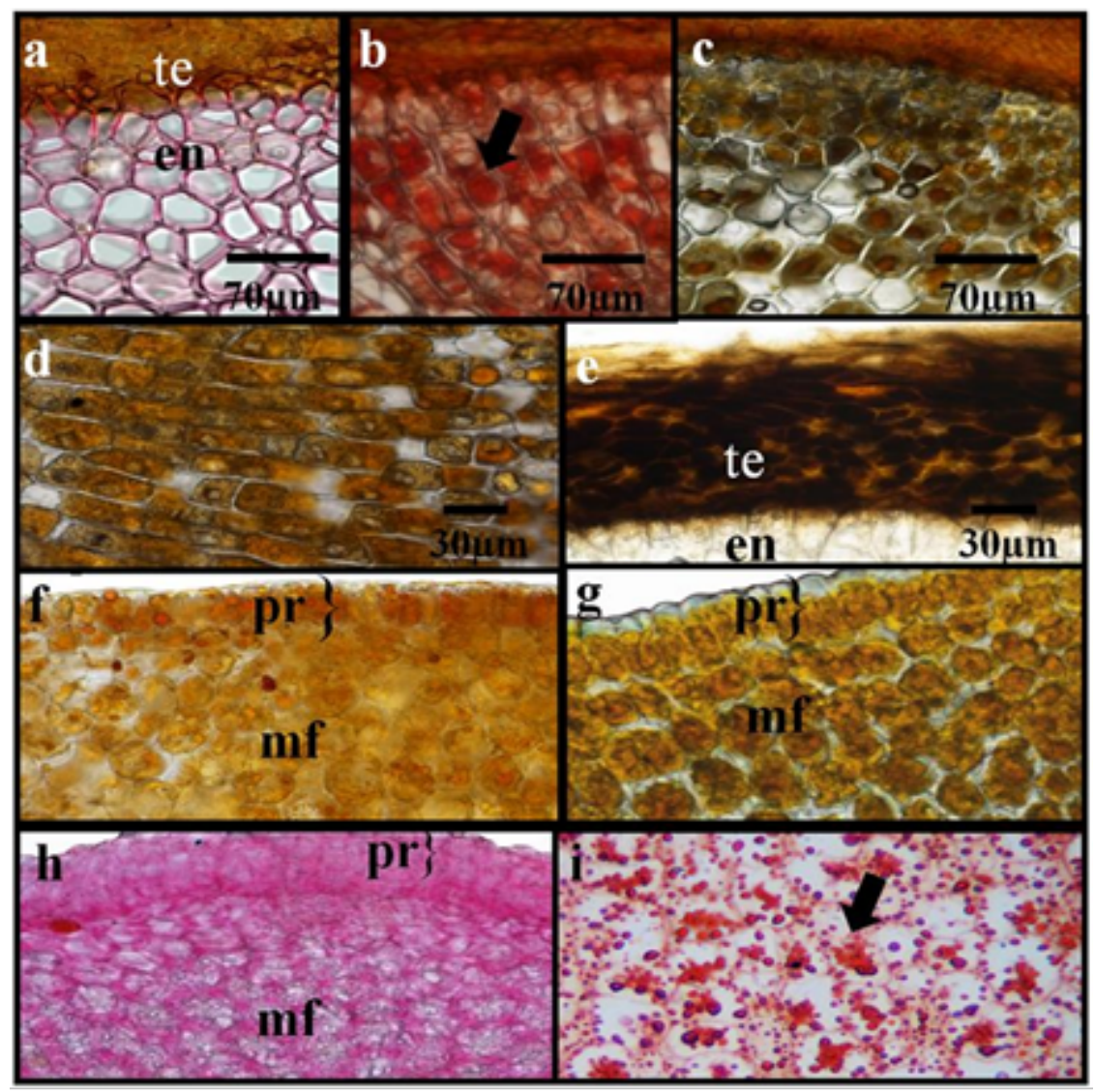

Figure 5. Histochemical tests applied on the Elaeis oleifera (Kunth) Cortés seed; a-e: seed coat and endosperm; f-i: embryo. a) Endosperm cell wall with pectin (ruthenium red). b) Endosperm stained with Xilidine Ponceau showing protein bodies (arrow). c) Endosperm cells with alkaloid concentration (Wagner). d) Lipids within the endosperm cells (Sudan). e) Seed coat with phenolic compounds (iron(III) chloride). f) Reaction for lipids within the protoderm cells and fundamental meristem. g) Protoderm cells and fundamental meristem with reaction for alkaloids. h) Reaction for pectin. i) Protein bodies within the cells of the fundamental meristem (arrow) (en: endosperm, mf: fundamental meristem, pr: protoderm, te: tegument).

The presence of lipids (Figure 5F), alkaloids (Figure 5G), pectin (Figure 5H), and proteins (Figure 5I) was identified in the protoderm and fundamental meristem of the embryo of E. oleifera. The presence of these compounds is a characteristic common to palm trees of different genera, such as Acrocomia aculeata (Moura et al., 2010) and Euterpe oleracea (Scherwinski-Pereira et al., 2012), and its existence contributes to embryo growth during the germination process as a food reserve.

\section{CONCLUSIONS}

The dense seed coat, of juxtaposed cells with phenolic composition, may contribute to impermeability to water, impeding gas diffusion and affecting germination. There is no embryonic immaturity in the seed, because the embryo has a conspicuous embryonic axis, composed of a plumule and radicle and distal region with differentiated haustorium without signs of morphological dormancy. 


\section{REFERENCES}

AGUIAR, M.O.; MENDONÇA, M.S. Morfo-anatomia da semente de Euterpe precatoria Mart. (Palmae). Revista Brasileira de Sementes, v.25, n.1, p.37-42, 2003. http://www.scielo.br/scielo.php?script=sci_arttext\&pid=S0101-31222003000100007

ARIAS, D.; GONZÁLEZ, M.; PRADA, F.; AYALA-DIAZ, I.; MONTOYA, C.; DAZA, E.; ROMERO, H.M. Genetic and phenotypic diversity of natural American oil palm (Elaeis oleifera (H.B.K.) Cortés) accessions. Tree Genetics and Genomes, v.11, n.122, p.1-13, 2015. https://link.springer.com/content/pdf/10.1007\%2Fs11295-015-0946-y.pdf

BARTON, L.V.; CROCKER, W. Physiology of seeds. LWW, 1953. 406.

BEWLEY, J.D. Seed germination and dormancy. The Plant Cell, v.9, p.1055-1066, 1997. http://www.plantcell.org/content/ plantcell/9/7/1055.full.pdf

BEWLEY, J.D.; BLACK, M. Physiology and biochemistry of seeds in relation to germination: volume 2: viability, dormancy, and environmental control. Springer Science \& Business Media. 2012, 376 p.

BRASIL. Ministério da Agricultura, Pecuária e Abastecimento. Regras para análise de sementes. Ministério da Agricultura, Pecuária e Abastecimento. Secretaria de Defesa Agropecuária. Brasília: MAPA/ACS, 2009. 395p. http://www.agricultura.gov.br/arq_editor/ file/2946_regras_analise_sementes.pdf

BALSLEV, H.; KRISTIANSEN, S.M.; MUSCARELLA, R. Palm community transects and soil properties in western Amazonia. Ecology, v.100, n.12, 2019. https://doi.org/10.1002/ecy.2841

BRUNDRETT, M.C.; KENDRICK, B.; PETERSON, C.A. Efficient lipid staining in plant material with sudan red 7B or fluoral yellow 088 in polyethylene glycol-glycerol. Biotechnology and Histochemistry, v.66, n.3, p.111-116, 1991. https://www.ncbi.nlm.nih.gov/ pubmed/1716161

BUCKERIDGE, M.S.; AIDAR, M.P.M.; SANTOS, H.P.; TINÉ, M.A. Acúmulo de reservas. In: FERREIRA, A.G.; BORGHETTI, F. (org.). Germinação: do básico ao aplicado. Porto Alegre: Artmed, 2004. p.31-50.

CAMILLO, J.; BRAGA, V.C.; MATTOS, J.K.A.; LOPES, R.; CUNHA, R.N.V.; PADILHA, J.; SCHERWINSKI-PEREIRA, J.E. Seed biometric parameters in oil palm accessions from a Brazilian germplasm bank. Pesquisa Agropecuária Brasileira, v.49, n.8, p.604-612, 2014. http://www.scielo.br/pdf/pab/v49n8/0100-204X-pab-49-08-00604.pdf

CARVALHO, N.M.; NAKAGAWA, J. Sementes: ciência, tecnologia e produção. $5^{\text {th }}$ ed. Jaboticabal: Funep, 2012. 590p.

CORLEY, R.H.V.; TINKER, P.B. The oil palm. $4^{\text {th }}$ ed. Great Britain: Blackwell Science, 2003.

CUNHA, R.N.V.; LOPES, R. BRS Manicoré: híbrido interespecífico entre o caiaué e o dendezeiro africano recomendado para áreas de incidência de amarelecimento fatal. Manaus: Embrapa Amazônia Ocidental, Comunicado técnico 85, 2010. https://www.infoteca. cnptia.embrapa.br/bitstream/doc/867099/1/ComTec852010.pdf

CUNHA, R.N.V.; LOPES, R.; ROCHA, R.N.C.; LIMA, W.A.A.; TEIXEIRA, P.C.; BARCELOS, E.; RODRIGUES, M.R.L.; RIOS, S.A. Domestication and breeding of the American oil palm. In: BORÉM, A.; LOPES, M.T.G.; CLEMENT, C.R.; NODA, H. (ed.). Domestication and breeding: Amazonian species. Viçosa: UFV, 2012. p.275-296.

CUNHA, R.N.V.; LOPES, R.; DANTAS, J.C.R.; ROCHA, R.N.C. Procedimentos para produção de sementes comerciais de dendezeiro na Embrapa Amazônia Ocidental. Manaus: Embrapa Amazônia Ocidental, Documentos, 2007. https://www.infoteca.cnptia.embrapa. br/bitstream/doc/681648/1/Doc54.pdf

DEBEAUJON, I.; LEPINIEC, L.; POURCEL, L.; ROUTABOUL, J.M. Seed coat development and dormancy. In: BRADFORD, K.; NONOGAKI, H. Seed development, dormancy and germination, p.25-49. Oxford: Blackwell Publishing, 2007. https://www.researchgate.net/ profile/Loic_Lepiniec/publication/227574619_Seed_Coat_Development_and_Dormancy/links/5751b63e08ae17e65ec34208.pdf

DeMASON, D.A. Endosperm structure and storage reserve histochemistry in the palm, Washingtonia filifera. American Journal of Botany, v.73, n.9, p.1332-1340, 1986. https://www.jstor.org/stable/2444067?seq=1\#page_scan_tab_contents

DeMASON, D.A.; THOMSON, W.W. Structure and ultrastructure of the cotyledon of date palm (Phoenix dactylifera L.). International Journal of Plant Sciences, v.142, n.3, 1981. https://www.journals.uchicago.edu/doi/pdfplus/10.1086/337230 
DRANSFIELD, J.; UHL, N.W.; ASMUSSEN, C.B.A.; BAKER, W.J.; HARLEY, M.M.; LEWIS, C. E. Genera Palmarum - the evolution and classification of palms. Royal Botanic Gardens: Kew Publishing, 2008.

ESAU, K. Anatomy of seed plants. $2^{\text {nd }}$ ed. New York: Edgard Blucher, 1977. 350p.

FURR, M.; MAHLBERG, P.G. Histochemical analyses of laticifers and glandular trichomes in Cannabis sativa. Journal of Natural Products, v.44, n.2, p.153-159, 1981. https://pubs.acs.org/doi/pdf/10.1021/np50014a002

GABE, M. Techniques histologiques. Paris: Masson et Cie, 1968. 1113p.

GENOVESE-MARCOMINI, P.R.; MENDONÇA, M.S.; CARMELLO-GUERREIRO, S.M. Morphoanatomy of the flower of Syagrus inajai (Spruce) Becc. (Arecaceae-Arecoideae-Attaleinae), Amazon. Brazilian Journal of Biology, v.73, n.3, p.649-661, 2013. http://www. scielo.br/pdf/bjb/v73n3/1519-6984-bjb-73-03-649.pdf

GREEN, M.; LIMA, W. A. A.; FIGUEIREDO, A.F.; ATROCH, A.L.; LOPES, R.; CUNHA, R.N.V.; TEIXEIRA, P.C. Heat treatment and seed germination of oil palm (Elaeis guineensis Jacq.). Journal of Seed Science, v.35, n.3, p.296-301, 2013. http://www.scielo.br/scielo. php?script=sci_arttext\&pid=S2317-15372013000300004

GONÇALVES, J.F.C.; LIMA, R.B.S.; FERNANDES, A.V.; BORGES, E.E.L.; BUCKERIDGE, M.S. Physiological and biochemical characterization of the assai palm (Euterpe oleracea Mart.) during seed germination and seedling growth under aerobic and anaerobic conditions. Revista Árvore, v.34, n.6, p.1045-1053, 2010. http://www.scielo.br/scielo.php?script=sci_arttext\&pid=S0100-67622010000600010

HENDERSON, A.J. Phenetic and phylogenetic analysis of Reinhardtia (Palmae). American Journal of Botany, v.89, n.9, p.1491-1502, 2002. https://www.ncbi.nlm.nih.gov/pubmed/21665751

HILHORST, H.W.M. Definitions and hypotheses of seed dormancy. In: BRADFORD, K.; NONOGAKI, H. Seed development, dormancy and germination. Oxford: Blackwell Publishing, 2007. p.50-71.

HORWITZ, W.; LATIMER, G. Official methods of analysis of AOAC International. Gaithersburg, MA, USA: Association of Official Analytical Chemistry, 2000.

HUSSEY, G. An analysis of the factors controlling the germination of the seed of the oil palm, Elaeis guineensis (Jacq.). Annals of Botany, v.22, n.2, p.259-284. 1958. https://academic.oup.com/aob/article-abstract/22/2/259/168532?redirectedFrom=fulltext

JENSEN, W.A. Botanical histochemistry: principles and practice. San Francisco: W.H. Freeman and Company, 1962. p.408.

JOHANSEN, D.A. Plant microtechnique. New York: McGraw-Hill, 1940. p.523.

KRAUS, J.E.; ARDUIN, M. Manual básico de métodos em morfologia vegetal. Seropédica: Edur, 1997. p.198.

LEITMAN, P.; HENDERSON, A.; NOBLICK, L.; MARTINS, R.C.; SOARES, K. Arecaceae na lista de espécies da flora do Brasil. Jardim Botânico do Rio de Janeiro. 2015. http://floradobrasil.jbrj.gov.br/jabot/floradobrasil/FB15732

LIMA, W.A.A.; GREEN, M.; ZEVIANI, W.M.; LOPES, R.; RIOS, S.A. Teor de água e tempo de exposição ao tratamento térmico na germinação de sementes de caiaué. Revista de Ciências Agrárias, v.60, n.2, p.192-198, 2017. https://periodicos.ufra.edu.br/index. php/ajaes/article/view/2625/1440

LIMA, W.A.A.; LOPES, R.; GREEN, M.; CUNHA, R.N.V.; ABREU, S.C.; CYSNE, A.Q. Heat treatment and germination of seeds of interspecific hybrid between American oil palm (Elaeis oleifera (H.B.K) Cortés) and African oil palm (Elaeis guineensis Jacq.). Journal of Seed Science, v.36, n.4, p.451-457, 2014. http://www.scielo.br/scielo.php?script=sci_arttext\&pid=S2317-15372014000400010\&lng=en\&tlng=en

LUTZ, I.A. Normas analíticas do Instituto Adolfo Lutz, v.1, 3ạ ed. São Paulo/SP: IAL, 1985. p.245-266.

MACHADO, W.; GUIMARÃES, M.F.; LIRA, F.F.; SANTOS, J.V.F.; TAKAHASHI, L.S.A.; LEAL, A.C.; COELHO, G.T.C.P. Evaluation of two fruit ecotypes (totai and sclerocarpa) of macaúba (Acrocomia aculeata). Industrial Crops and Products, v.63, p.287-293, 2015. https:// www.sciencedirect.com/science/article/pii/S0926669014006888

MARCOS-FILHO, J. Fisiologia de sementes de plantas cultivadas, $2^{\text {nd }}$ ed. Londrina, PR: ABRATES, 2015.660 p.

MARTIN, A.C. The comparative internal morphology of seeds. The American Midland Naturalist, v.36, n.3, p.513-660, 1946. https:// www.jstor.org/stable/2421457?seq=1 
MELO, G.A.M.; ARAÚJO, M.G.P.; STAUFFER, F. Fruit development and histochemistry of Attalea microcarpa Mart. (ArecaceaeArecoideae). Flora, v.235, p.10-17, 2017. https://doi.org/10.1016/j.flora.2017.08.004

MENDONÇA, M.S.D.; OLIVEIRA, A.B.; ARAÚJO, M.G.P.D.; ARAÚJO, L.M. Morpho-anatomy of the fruit and seed of Oenocarpus minor Mart. (Arecaceae). Revista Brasileira de Sementes, v.30, n.1, p.90-95, 2008. http://www.scielo.br/scielo.php?script=sci_ arttext\&pid=S0101-31222008000100012

MEUNIER, J. Le "palmier a huile" americain, Elaeis melanococca. Oléagineux, v.30, p.51-61, 1975.

MYINT, T.; CHANPRASERT, W.; SRIKUL, S. Germination of seed of oil palm (Elaeis guineensis Jacq.) as affected by different mechanical scarification methods. Seed Science and Technology, v.38, n.3, p.635-645, 2010. https://www.ingentaconnect.com/content/ista/ sst/2010/00000038/00000003/art00011

MOURA, R.C.; LOPES, P.S.N.; BRANDÃO-JUNIOR, D.S.; GOMES, J.G; PEREIRA, M.B. Biometria de frutos e sementes de Butia capitata (Mart.) Beccari (Arecaceae) em vegetação natural no norte de Minas Gerais, Brasil. Biota Neotropica, v.10, p.414-419, 2010a. http://www.scielo.br/scielo.php?pid=S1676-06032010000200040\&script=sci_abstract\&tlng=pt

MOURA, E.F.; VENTRELLA, M.C.; MOTOIKE, S.Y. Anatomy, histochemistry and ultrastructure of seed and somatic embryo of Acrocomia aculeata (Arecaceae). Scientia Agricola, v.67, n.4, p.399-407, 2010b. http://www.scielo.br/scielo.php?script=sci_ arttext\&pid=S0103-90162010000400004

NAZÁRIO, P.; FERREIRA, S.A.N.; GENOVESE-MARCOMINI, P.R.; MENDONÇA, M.S. Anatomical and histochemical aspects of the peach palm (Bactris gasipaes Kunth). Journal of Seed Science, v.35, n.2, p.171-178, 2013. http://www.scielo.br/pdf/jss/v35n2/05.pdf

O'BRIEN, T.P.; FEDER, N.; McCULLY, M.E. Polychromatic staining of plant cell walls by toluidine blue. Protoplasma, v.59, n.2, p.368373, 1964. http://www.cas.miamioh.edu/ meicenrd/Anatomy/Ch4_Histology/Polychromatic\%20staining\%20of\%20plant\%20cell\%20 walls\%20by\%20toluidine\%20blue\%200.pdf

O'BRIEN, T.P.; McCULLY, M.E. The study of plant structure: principles and selected methods. Melburne: Termarcaphi Pty Ltd, 1981. 46p.

OLIVEIRA, M.S.P.; RIOS, A.S. Potencial econômico de algumas palmeiras nativas da Amazônia. In: Encontro Amazônico de Agrárias. Atuação das ciências agrárias nos sistemas de produção e alterações ambientais. UFRA, 2014. http://www.bdpa.cnptia.embrapa. $\mathrm{br} /$ consulta/busca?b=ad\&id=994926\&biblioteca=vazio\&busca=994926\&qFacets=994926\&sort=\&paginacao=t\&paginaAtual=1

OLIVEIRA, N.C.C.; LOPES, P.S.N.; RIBEIRO, L.M.; MERCANDANTE-SIMÕES, M.O.; OLIVEIRA, L.A.A.; SILVÉRIO, F.O. Seed structure, germination and reserve mobilization in Butia capitata (Arecaceae). Trees, v.27 n.6, p.1633-1645, 2013. https://link.springer.com/ content/pdf/10.1007\%2Fs00468-013-0910-0.pdf

OLIVEIRA, A.B.; MENDONÇA, M.S.; ARAÚJO, M.G.P. Aspectos anatômicos do embrião e desenvolvimento inicial de Oenocarpus minor Mart: uma palmeira da Amazônia. Acta Botanica Brasilica, v.24, n.1, p.20-24, 2010. http://www.scielo.br/scielo.php?pid=S0102$33062010000100003 \&$ script $=$ sci_abstract $\&$ tlng=pt

PANZA, V.; LÁINEZ, V.; MALDONADO, S. Seed structure and histochemistry in the palm Euterpe edulis. Botanical Journal of the Linnean Society, v.145, n.4, p.445-453, 2004. https://academic.oup.com/botlinnean/article/145/4/445/2420270

REES, A.R. High-temperature pre-treatment and germination of seed of oil palm, Elaeis guineensis (Jacq.). Annals of Botany, v.26, n.4, p.569-581, 1962. https://academic.oup.com/aob/article-abstract/26/4/569/100667?redirectedFrom=fulltext

RIBEIRO, L.M.; OLIVEIRA, D.M.T.; GARCIA, Q.S. Structural evaluations of zygotic embryos and seedlings of the macaw palm (Acrocomia aculeata, Arecaceae) during in vitro germination. Trees, v.26, p.851-863, 2012. https://www.researchgate.net/profile/ Denise_Oliveira5/publication/257431414_Structural_evaluations_of_zygotic_embryos_and_seedlings_of_the_macaw_palm_ Acrocomia_aculeata_Arecaceae_during_in_vitro_germination/links/00b7d525bcfae01340000000.pdf

RIOS, S.D.A.; CUNHA, R.N.V.; LOPES, R.; SILVA, E.B. Recursos genéticos de palma de óleo (Elaeis guineensis Jacq.) e Elaeis oleifera (Elaeis oleifera (hbk) Cortés). Embrapa Amazônia Ocidental-Documentos, 2012. https://www.embrapa.br/busca-de-publicacoes/-/ publicacao/949588/recursos-geneticos-de-palma-de-oleo-elaeis-guineensis-jacq-e-caiuae-elaeis-oleifera-h-b-k-cortes

RODRIGUES, J.K.; MENDONÇA, M.S.; OLIVEIRA GENTIL, D.F.O. Aspectos biométricos e morfoanatômicos do pireno e da semente e histoquímica da semente de Bactris maraja Mart. (Arecaceae). Rodriguésia, v.66, n.1, p.75-85, 2015. https://rodriguesia-seer.jbrj. gov.br/index.php/rodriguesia/article/view/944/pdf_156 
SCHERWINSKI-PEREIRA, J.E.; GUEDES, R.S.; SILVA, R.A.; FERMINO-JUNIOR, P.C.P.; LUIS, Z.G.; FREITAS, E.O. Somatic embryogenesis and plant regeneration in açaí palm (Euterpe oleracea). Plant Cell, Tissue and Organ Culture, v.109, p.501-508, 2012. https://link. springer.com/content/pdf/10.1007\%2Fs11240-012-0115-z.pdf

SILVA, R.S.; RIBEIRO, L.M.; MERCADANTE-SIMÕES, M.O.; NUNES, Y.R.F.; LOPES, P.S.N. Seed structure and germination in buriti (Mauritia flexuosa), the Swamp palm. Flora - Morphology, Distribution, Functional Ecology of Plants, v.209, n.11, p.674-685, 2014. https://www.sciencedirect.com/science/article/pii/S0367253014001212

SOUZA, J.N.; RIBEIRO, L.M.; MERCADANTE-SIMÕES, M.O. Ontogenesis and functions of saxophone stem in Acrocomia aculeata (Arecaceae). Annals of Botany, v.119, n.3, p.353-365, 2017. https://academic.oup.com/aob/article/119/3/353/2901737

TAIZ, L.; ZEIGER, E. Fisiologia vegetal, $4^{\text {th }}$ ed. Porto Alegre: Artmed, 2009. 848p.

TOKUHISA, D.; DIAS, D.C.F.S.; ALVARENGA, E.M.; DIAS, L.A.S.; MARIN, S.L.D. Tratamentos para superação da dormência em sementes de mamão. Revista Brasileira de Sementes, v.29, n.1, p.131-139, 2007. http://www.scielo.br/pdf/rbs/v29n1/18.pdf

TOMLINSON, P.B. The structural biology of palms. Oxford: Clarendon Press, 1990. 477p.

WERKER, E. Seed anatomy. Stuttgart: Borntraeger, 1997. 424p. use, distribution, and reproduction in any medium, provided the original work is properly cited. 